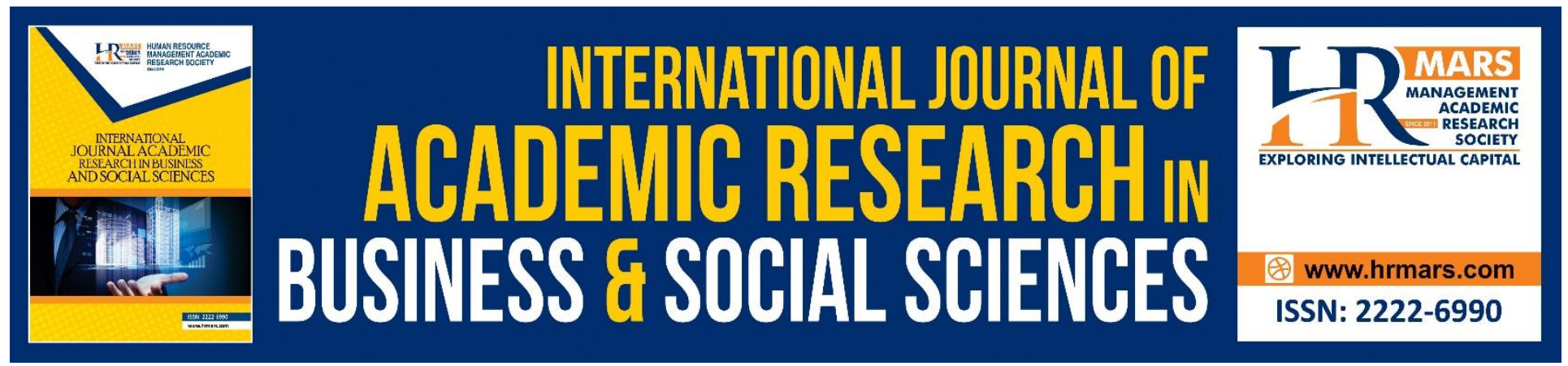

\title{
The Suitable Teaching Methods in Entrepreneurship Education from the Perspective of Undergraduate Students
}

Norsamsinar Samsudin, Bahijah Abas, Siti Asma' Rosdi, Ahmad Zainal Abidin Abdul Razak

To Link this Article: http://dx.doi.org/10.6007/IJARBSS/v9-i2/5618

DOI: $\quad 10.6007 /$ IJARBSS/v9-i2/5618

Received: 26 Jan 2019, Revised: 22 Feb 2019, Accepted: 11 March 2019

Published Online: 13 March 2019

In-Text Citation: (Samsudin, Abas, Rosdi, \& Razak, 2019)

To Cite this Article: Samsudin, N., Abas, B., Rosdi, S. A., \& Razak, A. Z. A. A. (2019). The Suitable Teaching Methods in Entrepreneurship Education from the Perspective of Undergraduate Students. International Journal of Academic Research in Business and Social Sciences, 9(2), 818-825.

Copyright: (C) 2019 The Author(s)

Published by Human Resource Management Academic Research Society (www.hrmars.com)

This article is published under the Creative Commons Attribution (CC BY 4.0) license. Anyone may reproduce, distribute, translate and create derivative works of this article (for both commercial and non-commercial purposes), subject to full attribution to the original publication and authors. The full terms of this license may be seen

at: http://creativecommons.org/licences/by/4.0/legalcode

Vol. 9, No. 2, 2019, Pg. 818 - 825

http://hrmars.com/index.php/pages/detail/IJARBSS

JOURNAL HOMEPAGE

Full Terms \& Conditions of access and use can be found at http://hrmars.com/index.php/pages/detail/publication-ethics 


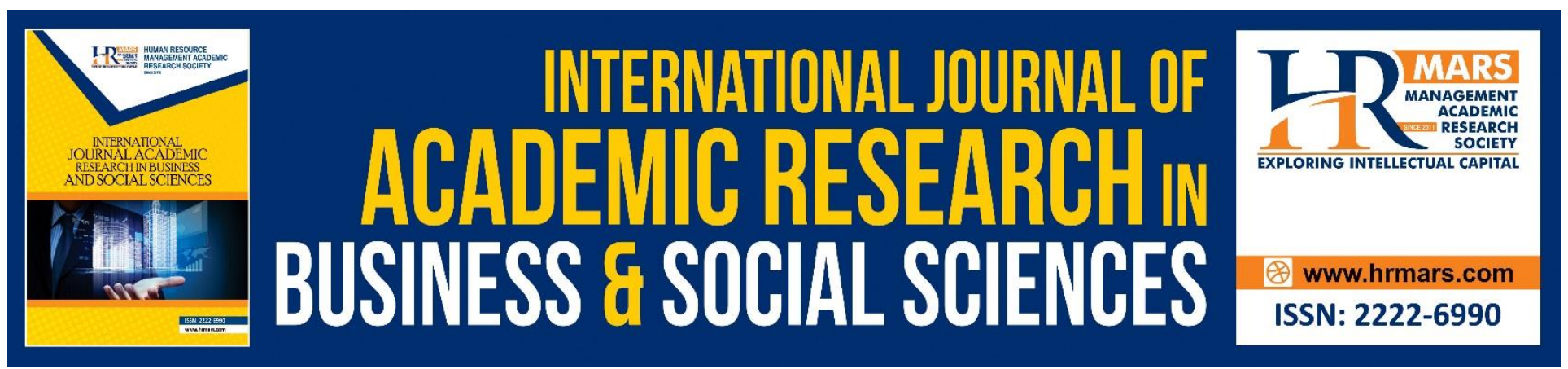

\title{
The Suitable Teaching Methods in Entrepreneurship Education from the Perspective of Undergraduate Students
}

\author{
Norsamsinar Samsudin ${ }^{1}$, Bahijah Abas ${ }^{2}$, Siti Asma' Rosdi ${ }^{3}$, Ahmad \\ Zainal Abidin Abdul Razak ${ }^{4}$ \\ 1,2,3,4 Universiti Pendidikan Sultan Idris, Malaysia
}

\begin{abstract}
This study aims to investigate the suitability of teaching methods of the Entrepreneurship Enculturation Course in the Malaysian public education university. The target population of the study is 1700 students in the university enrolled the mentioned course. A set of questionnaires is used as an instrument to collect the required data. Data was analyzed using descriptive statistic to get the mean and standard deviation. The findings of the study provide insights to academics, educators, policy makers, and practitioners about the suitability of teaching methods in entrepreneurship course.
\end{abstract}

Keywords: Entrepreneurship Education, Teaching Method

\section{Introduction}

Malaysia is a developing country with emerging of the economic, educational, socio-cultural, and infrastructure sectors. Business and entrepreneurship are the most important economic sectors contributing to the development of the national economy. The current economic situation urges Malaysians to involve in entrepreneurship to have better quality of life in terms of financially and stability (Nor Fadhilah \& Halimah, 2010). Entrepreneurship is one of the opportunities for Malaysian to create their own job as well as provide job to others. However, most of young Malaysians preferred to venture in private sectors or choose to be a government servant (Noraini \& Norisham, 2011). However, Norasmah and Hanisah (2017) reported the data from the labor statistics of November 2015 issued by Malaysian Statistic Department, in which 45,300 graduates were unemployed. This was an increment of 3.3\% in 2015 as compared to $2.8 \%$ in 2014.

In other report, The Global Entrepreneurship Monitor (GEM) 2015 highlights that 42\% of workingage adults in the GEM economies regions (i.e., Africa, Asia \& Oceania, Latin America \& Caribbean, Europe, and North America) possessed high inclination and readiness towards starting a business. 
However, the intention to become an entrepreneur among Malaysian working-age adults was only $5.7 \%$. This figure was among the lowest as compared to other countries. In addition, the fear of failure was among the highest percent $(27.1 \%)$ as compared to others.

Malaysia has introduced Malaysia Education Blueprint (Higher Education), a strategic document prepared by the Malaysia Ministry of Education, which sets direction of higher education for a period of 11 years from 2015 until 2025. The blueprint aims to elevate the higher education system of the country in order to produce world class graduates. It consists of 10 shifts that will spur the excellence of Malaysia higher education system. The number one shift that has been outlined is focus on producing holistic, entrepreneurial and balanced graduates. The aims of this first shift is to instill an entrepreneurial mindset throughout Malaysia's higher education system and create a system that produces graduates with a drive to create jobs, rather than to only seek jobs.

Various forms of entrepreneurship programs have been organized in higher education as efforts to achieve the government's objectives. The MOE has planned Students Entrepreneurship Enculturation program that consists of four main activities. The first is a module of entrepreneurship, a two credit hours course that is compulsory for semester one students. The second activity is the five days Basic Entrepreneurship Course for final year students. The third activity is Students Entrepreneur Development Program that aims to encourage students to do business activities in campus, set up a company, visits industry, and organized seminars. The fourth activity is the Enactus program which aims to encourage students to carry out social entrepreneurship activities to enhance social and economic status of the local community (Wan Mohd Zaifurin \& Noorun Nashriah, 2009). Therefore, entrepreneurship educators play important roles to ensure the entrepreneurship pedagogical approaches are suitable and enable to achieve the aim learning outcomes.

\section{Literature Review}

The Malaysian Higher Education Ministry launched the Higher Education Institution Entrepreneurship Action Plan 2016-2020, a strategic document to implement and develop entrepreneurial education at Higher Education Institutions (HEIs). It was a continuation of the HEI Entrepreneur Development Policy launched in April 13, 2010 and the HEI Entrepreneur Strategic Plan 2013-2015 that helped improve the involvement and participation of students in business activities. The action plan has four initiatives based on two strategies under the education blueprint Shift 1, focusing on the development of students and system aspirations in producing holistic, balanced and entrepreneurial graduates. The four initiatives include high impact education practices, job creator framework, improving the student entrepreneur development support ecosystem, and strengthening the entrepreneur teaching force competency (Rozana, 2017). Thus, educators in the context of teaching and learning of entrepreneurship must ensure the most appropriate approaches that will assist the accomplishment of the learning objectives.

Entrepreneurship education focus on cultivating the spirit and culture of entrepreneurship, strengthening professional qualities (i.e., leadership, risk taking ability, teamwork, etc), expanding ways to employment, and provide knowledge, skills and motivation (Ediabonya, 2013). Samsudin et 
al., (2015) revealed that the readiness level to get involve in entrepreneurship among final year students were at the moderate level. Their attitudes and motivation towards entrepreneurship also at the moderate level. The correlation analysis found a strong, significant positive relationship between readiness, motivation and attitudes towards entrepreneurship.

In other research, Sandhu et. al., (2011) conducted a study on entrepreneurial inclination among postgraduate students in Malaysia and found that the inclination level towards entrepreneurship was high. The result also showed that 31.5 percent of the variation in the entrepreneurial inclination is explained by five barriers (i.e., aversion to risk, fear of failure, lack of resources, narrow social networking, stress and hard work aversion). Similarly, Gelderen, Brand, Praag, Bodewes, Poutsma and Gils (2008) conducted a study on entrepreneurial intention among 1,225 business students at four universities in Netherland. They found that more than $50 \%$ of the respondents have high inclination to set up a business, but $75 \%$ of them were set back when considering actual constraints in business world. Although most of the respondents in the study were not from business family background, but most of them participated in entrepreneurship activities organized by the university. As suggested by Buerah Tunggak and Hussin Salamon (2008), formal education, business experience and frequency of attending an entrepreneurship training program are among the important factors that affect individuals' involvement in entrepreneurship. Successful entrepreneur has appropriate skills and knowledge in their business. They develop their skills and knowledge, either formal or informal through past experiences (Ishak Yusof et al., 2011).

Many of the previous studies claimed that entrepreneurship education has focused on developing a business plan, visit from experts, case studies, assignment project related to business development, and some limited hands-on approach. However, there are no many researches investigate the effectiveness or the impact of different approaches on the entrepreneurship outcomes (Sherman, Sebora \& Digman, 2008). It is important for educators to continuously improve their methods and teaching styles through the assessment of the effectiveness of the pedagogical approaches (Sherman et al., 2008). Students with entrepreneurship education have a higher intention and greater attitudes to become entrepreneurs and start up a business (Mueller, 2011; Soutaris et al., 2007; Fayolle et al., 2005). However, studies in Malaysia revealed that the percentage of graduate entrepreneurs was low (Nor Aishah, 2013). Thus, the purpose of this paper was to investigate the suitability of teaching and learning methods of entrepreneurship on students' perspective. With this, it is expected that the intention to become an entrepreneur among the students will increase.

\section{Methodology}

The target population of this survey study is 1700 students in one of the public education university in Malaysia, enrolled in Entrepreneurship Enculturation Course. The sample of 313 students were randomly selected from the study population (Krecjie \& Morgan,1970). A set of questionnaires is used as an instrument to collect the required data. The returned percentage of the questionnaires was $83 \%$ ( 250 sets). This percentage is acceptable to conduct a survey study (Cohen et al., 2001). Data was analyzed using descriptive statistic to get the mean and standard deviation. 
INTERNATIONAL JOURNAL OF ACADEMIC RESEARCH IN BUSINESS AND SOCIAL SCIENCES

Vol. 9, No. 2, Feb, 2019, E-ISSN: 2222-6990 C 2019 HRMARS

\section{Research Findings}

The findings of the study are presented in Table 1. The results showed that the most five preferable methods in learning entrepreneurship from the perspective of undergraduates students are industry visit $(M=5.08, S D=.966)$, interactive lecture $(M=5.06, S D=.976)$, ideation and innovation activities $(M=5.04, S D=.946)$, Business Model Canvas activity $(M=4.99, S D=.945)$, and group assignment $(M=4.97, S D=1.021)$. The least preferable methods are forum online $(M=4.75, S D=1.166)$ and business simulation $(M=4.86, S D=1.113)$. However, the scores for overall methods were high. This means that all pedagogical approaches utilized in entrepreneurship education is suitable with students' expectation on how the class will be conducted.

Table 1: Methods in Entrepreneurship Education

\begin{tabular}{lcc}
\hline \multicolumn{1}{c}{ Methods } & Mean & SD \\
\hline Case study & 4.88 & 1.152 \\
Industry speaker & 4.84 & 1.018 \\
Group discussion & 4.92 & 1.063 \\
Interactive lecture & 5.06 & .976 \\
Role play & 4.88 & 1.092 \\
Entrepreneurship interview & 4.89 & 1.102 \\
Group assignment & 4.97 & 1.021 \\
Business simulation & 4.86 & 1.113 \\
Business activity & 4.90 & 1.044 \\
Problem solving & 4.93 & 1.036 \\
Industrial attachment & 4.91 & .995 \\
Industry visit & 5.08 & .966 \\
Social entrepreneurship activity & 4.94 & 1.142 \\
Online forum & 4.75 & 1.166 \\
BMC activity & 4.99 & .945 \\
Ideation and innovation activity & 5.04 & .946 \\
\hline
\end{tabular}

The intention of becoming an entrepreneur among students was associated with entrepreneurship education approaches (Mueller, 2011). Previous studies have categorized the teaching and learning methods of entrepreneurship education into two category: traditional methods which considered as passive method (i.e., normal lectures, case studies, group discussion) and innovative methods which considered as active methods (i.e., action-based methods like study visits, real small business ventures, guest speakers, business plan creation, games, written report, group project, presentation) (Lonappan et al., 2011; Mwasalwiba, 2010; Fayolle et al., 2008). Arasti, Falavarjani and Imanipour (2012) discovered that active methods were more effective on nurturing entrepreneurship attributes among students as compared to traditional methods. 


\section{Conclusion}

This study highlights the suitable methods of teaching and learning entrepreneurship from the perspective of undergraduate students. The findings of this study revealed that students are fine with the all methods that have been investigated. However, the most preferable methods are industry visit, interactive lecture, and ideation and innovation activities. The results of the study provide more insights to entrepreneurship educators on how to conduct more effective class. This study has been conducted in one of the public education university in Malaysia. Therefore, the results cannot be generalized to broader population of higher education landscape. Future research is recommended to measure the effects of teaching and learning methods of entrepreneurship on the university students' inclination for business start-up.

\section{References}

Arasti, Z., Falavarjani, M. K. \& Imanipour, N. (2012). A study of teaching methods in entrepreneurship education for graduate students. Higher Education Studies, 2 (1), 2-10. Doi: 10.5539/hes.v2n1p2

Buerah binti Tunggak \& Hussin bin Salamon (2014). “Perubahan Sikap Keusahawanan Usahawan Melayu Di Malaysia". Journal of Social Sciences and Humanities, 9 (1), 098-116.

Cohen, L., Manion, L. \& Morisson, K. (2001). Research Methods in Education. 5th Edition. London: Routledge Falmer.

Ediabonya, K. (2013). The roles of entrepreneurship education in ensuring economic empowerment and development. Journal of Business Administration and Education, 4 (1), 35-46.

Fayolle, A., Gailly, B. \& Lassas-Clerc, N. (2005). Capturing variations in attitudes and intentions: a longitudinal study to assess the pedagogical effectiveness of entrepreneurship teaching programs. Paper presented at the International Council for Small Business (ICSB) World Conference, Washington DC, USA, 15-18 June.

Gelderen, M., Brand, M., Praag, M., Bodewes, W., Poutsma, E., \& Gils, A. (2008). Explaining entrepreneurial intentions by means of the theory of planned behaviour. Career Development International, 13(6): 538-559

Ishak Yusof, Khairunnisa Mardzuki, Zaimah Darawi dan Mohd Shukri Hajinoor (2011). "Faktor Keusahawanan dan Prestasi Kejayaan Usahawan Melayu di Pulau Langkawi, Kedah." Prosiding PERKEM VI, Jilid 2 (2011) 196-207

Krejcie, R. V. \& Morgan, D. W. (1970). Determining sample size for research activities. Retrieved from https://journals.sagepub.com/doi/pdf/10.1177/001316447003000308 
INTERNATIONAL JOURNAL OF ACADEMIC RESEARCH IN BUSINESS AND SOCIAL SCIENCES

Vol. 9, No. 2, Feb, 2019, E-ISSN: 2222-6990 C 2019 HRMARS

Lonappam, J. \& Devaraj, K. (2011). Pedagogical Innovations in Teaching

Entrepreneurship. International Conference on Management, pp 513-518.

Mueller, S. (2011). Increasing entrepreneurial intention: effective entrepreneurship course characteristics. International Journal of Entrepreneurship and Small Business, 13(1), 55-74.

Mwasalwiba, E. S. (2010). Entrepreneurship education: a review of its objectives, teaching methods, and impact indicators. Education and Training. 52 (1). 20-47. Doi:

10.1108/00400911011017663.

Nor Aishah, B. (2013), "Kajian keperluan pendidikan keusahawanan secara formal dalam kalangan pelajar Fakulti Kejuruteraan dan Alam Bina dan Fakulti Pendidikan", Universiti Kebangsaan Malaysia, retrieved from: www.ukm.my/p3k/images/sppb08/d/7.pdf

Noraini Mohd Noor \& Norisham A. Rahim. (2011). Kecenderungan pelajar-pelajar Institut Kemahiran Mara (IKM) Johor Bharu terhadap bidang keusahawanan.

Noraini, A.J. (2018). Trend pengangguran dalam kalangan graduan di Malaysia. (Thesis Ijazah Sarjana Muda). Retrieved from http://ethesis.uthm.edu.my/454/1

Rozana, S. (2017, December 27). Entrepreneurship: Pushing the agenda further. The New Straits Time.

Samsudin, N., Ab Jalil, N., Ab Wahid, H., Yahaya, R. \& Mat Jizat, J. E. (2016). Students' Readiness, Motivation and Attitude towards Entrepreneurship. International Business Education JournalIBEJ, 9 (1). pp. 50-57. ISSN 1985-2126

Sandhu, S.M., Sidique, F.S. and Riaz, S. (2010), "Entrepreneurial barriers and entrepreneurial inclination among Malaysia postgraduate students", International Journal of Entrepreneurial Behavior \& Research , Vol. 17 No. 4, pp. 428-229.

Sherman, P. S., Sebora, T. \& Digman, L. A. (2008). Experiential entrepreneurship in the classroom: effects of teaching methods on entrepreneurial career choice intentions. Journal of Entrepreneurship Education, 11, 29-42.

Souitaris, V., Zerbinati, S. \& Al-Laham, A. (2007). Do entrepreneurship programmes raise entrepreneurial intention of science and engineering students? The effect of learning, inspiration and resources. Journal of Business Venturing, 22(4), 566-591. 
INTERNATIONAL JOURNAL OF ACADEMIC RESEARCH IN BUSINESS AND SOCIAL SCIENCES

Vol. 9, No. 2, Feb, 2019, E-ISSN: $2222-6990$ ๑ 2019 HRMARS

\section{Acknowledgements}

This research is funded by Universiti Pendidikan Sultan Idris Research Grant (2017-0256-107-01).

\section{Corresponding Author}

Dr. Norsamsinar Samsudin

Department of Business Management and Economics, Faculty of Business and Management

Universiti Pendidikan Sultan Idris, 35900 Tanjong Malim,

Malaysia.

Email: norsamsinar@fpe.upsi.edu.my 